\title{
ARTICLES
}

\section{Full results of the genome-wide scan which localises a locus controlling the intensity of infection by Schistosoma mansoni on chromosome 5q31-q33}

\author{
Sandrine $\mathrm{M}$ arquet $^{1}$, Laurent $\mathrm{A}$ bel $^{2}$, Dominique Hillaire ${ }^{1}$ and A lain Dessein ${ }^{1}$ \\ ${ }^{1}$ I mmunology and G enetic of Parasitic D iseases/L aboratory Parasitology-M ycology, Faculty of M edicine, M arseille, \\ France \\ ${ }^{2} \mathrm{M}$ athematical and Statistical M odelling in B iology and M edicine, $\mathrm{H}$ ospital Pitié-Salpêtrière, Paris, France
}

Three hundred million individuals are at risk of infection by schistosomes, and thousands die each year of severe hepatic disease. Previous studies have shown that the intensity of infection by Schistosoma mansoni in a B razilian population is controlled by a major gene, denoted as SM 1. We report here the full results of a genome-wide search that was performed on this population to localise SM 1 . Two hundred and forty-six microsatellites were used for the primary map, and only one region in 5q31-q33 provided significant evidence of linkage. SM 1 was subsequently mapped to this region, which contains several genes encoding cytokines or cytokine receptors which are involved in protection against schistosomes. Three additional regions, 1p22.2, 7q36 and 21q22-22-qter, yielded promising, although not significant, lod-score values. These regions contain candidate genes encoding cytokines or molecules relevant to anti-schistosome immunity.

Keywords: genome-wide scan; schistosomiasis; susceptibility gene; intensity of infection

\section{Introduction}

Schistosomiasis affects 300 million people throughout the world, and is a major public health problem in many developing countries. ${ }^{1}$ The disease is spreading with the implementation of irrigation schemes in developing areas, and is caused by eggs laid by schistosome worms which live for years in the mesenteric and portal veins

Correspondence: Professor A lain D essein, Laboratoire d'Immunologie et $\mathrm{G}$ énétique des $M$ aladies Parasitaires, IN SE R M U.399, Faculté de M édecine, U niversité de la M éditerranée, 27 Bd J ean M oulin, 13385 M arseille Cedex 05, France. Tel: 33 4913244 52/53; Fax: 334917960 63; E-mail: A lain.D essein@medecine.univ-mrs.fr

R eceived 17 March 1998; revised 2 June 1998; accepted 19 J une 1998 of their human host. Humans become infected when they bathe in waters infested by free-swimming schistosome larvae released by the molluscan vector. Eggs trigger an intense and chronic inflammatory reaction which causes fibrotic disease. In certain individuals, extended periportal fibrosis leads to severe portal hypertension and these subjects may die of haematemesis, co-infections or heart failure.

Severe clinical disease in schistosomiasis is often due to long-standing severe infections. Infection levels were shown to depend to a large extent on the resistance/ susceptibility status of exposed subjects, and epidemiological studies performed in a Brazilian population indicated that individuals with the highest susceptibility were grouped within certain families, rather than 
randomly distributed. These observations suggested that human susceptibility/resistance to infection by $\mathrm{S}$. mansoni was genetically determined. ${ }^{2-5}$ To investigate whether a major gene controls human levels of infection by $\mathrm{S}$. mansoni, segregation analysis of infection intensities, adjusted for water contact, age and sex was performed on 20 Brazilian pedigrees comprising 269 individuals, ${ }^{6}$ and led to the detection of a co-dominant major gene controlling the infection by S. mansoni. The frequency of the allele predisposing to high infection levels was $0.20-0.25$, indicating that about $5 \%$ of the population was predisposed to high infection, $60 \%$ was resistant, and $35 \%$ had intermediate levels of resistance. To confirm the existence of this gene and to localise it, a genome-wide scan was performed on 142 $B$ razilian subjects belonging to 11 informative families. The parametric linkage analysis indicated the existence of this major locus and allowed us to map the gene to chromosome $5 .^{7}$ This linkage analysis was the first successful mapping of a gene involved in infectious diseases using a genome-wide search strategy, and demonstrates the feasibility of such an approach. For this reason, we report here the full results of this analysis indicating the other genetic regions of interest in addition to the $5 q 31-q 33$ region which was published previously in a short report. $^{7}$

\section{Materials and Methods}

\section{Study Area and Subjects}

Study subjects live in a small village, Caatinga do Moura, in the north-east of Brazil where $\mathrm{S}$. mansoni is endemic. A II individuals in the population were infected because most agricultural and domestic activities require contact with an infested river. The measurements of individual exposure to infection and the determination of the phenotypes measuring susceptibility to $\mathrm{S}$. mansoni infection have been extensively described in previous papers. ${ }^{8,9}$ Infection intensities were measured by individual foecal egg counts prior to any treatment, expressed in eggs/gram and noted as $\mathrm{E} 1$ values.

\section{Preparation of DNA}

Blood samples were collected from 142 subjects either on ethylenediaminetetra acetic acid (E DTA) or on Na-heparine and frozen immediately at $-80^{\circ} \mathrm{C}$. DNA was extracted from human blood samples according to the following protocol: $6 \mathrm{ml}$ of blood were thawed, and incubated for $30 \mathrm{~min}$ with $30 \mathrm{ml}$ of blood lysis buffer $\mathrm{pH} 7.4\left(7.75 \mathrm{~mm} \mathrm{NH}{ }_{4} \mathrm{Cl}, 0.5 \mathrm{~mm}\right.$ $\mathrm{KHCO}_{3} 0.05 \mathrm{~mm}$ EDTA pH 7.4) at room temperature. Then samples were centrifugated at $3000 \mathrm{rpm}$ for $10 \mathrm{~min}$ at $4^{\circ} \mathrm{C}$, pellets were washed three times with $30 \mathrm{ml}$ of the same buffer, and finally resuspended in $3 \mathrm{ml}$ of lysing buffer $10 \mathrm{~mm}$ Tris$\mathrm{HCL}, 400 \mathrm{~mm} \mathrm{NaCl}, 2 \mathrm{~mm} \mathrm{Na}_{2}$ EDTA pH 8.2, and $1 \%$ SDS was added. Samples were then digested overnight with $100 \mu$ l proteinase $\mathrm{K}(20 \mathrm{mg} / \mathrm{ml})$ at $37^{\circ} \mathrm{C} .1 \mathrm{ml}$ of $\mathrm{NaCl} 6 \mathrm{M}$ was added followed by centrifugation at $3600 \mathrm{rpm}, 20 \mathrm{~min}$ at room temperature. D NA was precipitated in the supernatant using standard methods ${ }^{10}$ and kept at $-20^{\circ} \mathrm{C}$ until use.

\section{Genotyping using Microsatellites}

G enomic DNA was diluted to a concentration of $4 \mu \mathrm{g} / \mathrm{ml}$ for amplification. M icrosatellites were amplified by the PCR in 96-well Falcon flexi plates as described. ${ }^{11}$ PCR was performed in $50 \mathrm{ul}$ containing $40 \mathrm{ng}$ of genomic D NA, $10 \mathrm{~mm}$ Tris- $\mathrm{HCL}$, $\mathrm{pH} 8.8,50 \mathrm{~mm} \mathrm{KCl}, 1.5 \mathrm{~mm} \mathrm{M} \mathrm{gCl}, 0.1 \%$ Triton, $1 \mu \mathrm{m}$ of each primer, $31 \mu \mathrm{M}$ of each dNTP (B oehringer M annheim, M eylan, France) and $1 \mathrm{U}$ of Taq DNA polymerase (Perkin-Elmer). Cycle conditions were $96^{\circ} \mathrm{C}$ for $5 \mathrm{~min}, 94^{\circ} \mathrm{C}$ for $10 \mathrm{~min}$ 'hot start', followed by 35 cycles of $92^{\circ} \mathrm{C}$ for $40 \mathrm{~s}, 55^{\circ} \mathrm{C}$ for $30 \mathrm{~s}$, $72^{\circ} \mathrm{C}$ for $10 \mathrm{~S}$ and finally $72^{\circ} \mathrm{C}$ for $10 \mathrm{~min}$. The amplification reaction products for 16 microsatellites were pooled and aliquots were precipitated and resuspended in $5 \mu \mathrm{l} \mathrm{TE} \mathrm{10:1.}$ $5 \mu \mathrm{l}$ of loading buffer ( $80 \%$ formamide, $20 \%$ bromophenol and xylen blue) was added and samples were heated at $96^{\circ} \mathrm{C}$ for 2 min. A $4 \mu$ l aliquot of each sample was separated on a $6 \%$ denaturing polyacrylamide gel. G els were transferred by capillary action to a nylon membrane overnight and hybridised with peroxydase labelled specific primers (using $E C L$ direct nucleic acid labelling and detection systems R PN 3001 (A mersham, Les ulis, France) and added at a $15 \mathrm{ng} / \mathrm{ml}$ concentration. ${ }^{11}$ Separated PCR products were visualised by autoradiography (A mersham R PN 7 films). G enotypes were determined by two independent observers for each autoradiograph.

E leven additional markers were analysed in the 5q31-q33 region including $8 \mathrm{G}$ énéthon markers (Figure 1 ). The three remaining markers were intragenic, using the following primers (annealing temperatures in parentheses): interleukin4 (IL 4-RP1) (Third intron), 5'- CTCAAAGTGCTGGGATTAGC-3' and 5'-A GCCATCTCGGTTGGATGGA-3' $\left(57^{\circ} \mathrm{C}\right) ;^{12}$ interleukin-9 (IL 9) (fourth intron) 5'-AGGCTTTCTCTAATGCAGAG-3' and 5'-GGTGGTTGACCTCAA ATTG G-3' $\left(53^{\circ} \mathrm{C}\right) ;^{13}$ colony stimulating factor 1 receptor (CSF 1R) (second intron) 5'-TGTGTCCAGCCTTAGTGTGCA $-3^{\prime}$ and 5'-TCATCACTTCCAGAATGTGC$3^{\prime}\left(53^{\circ} \mathrm{C}\right) .^{14}$

\section{Segregation Analysis}

E vidence for the segregation of a major gene controlling $S$. mansoni infection levels was obtained in this Brazilian population in $1991 ; 6$ in this study, phenotypes were adjusted on the covariates before the segregation analysis. Since this early publication, more information has been obtained on familial relationships, and a refined segregation analysis was performed by taking into account the covariates (water contact, age, sex) that had a significant effect on infection intensity, simultaneously with the major gene effect. M oreover, the phenotypes of the subjects with the lower water contact exposure were considered as unknown, since a significant proportion of these subjects did not have any contact with the river and provided meaningless null E 1 value.

Segregation analysis was performed using the regressive models for continuous phenotypes developed by Bonney. ${ }^{15}$ These regressive models are constructed by specifying a regression relationship between the phenotype (logarithmic transformation of E 1 values noted as E 2) and a major gene effect, the phenotype of relatives and covariates. The parameters of the major gene effect are $q$, the frequency of $A$, the allele predisposing to high infection levels, and the three 
Chromosome 5 cM Markers

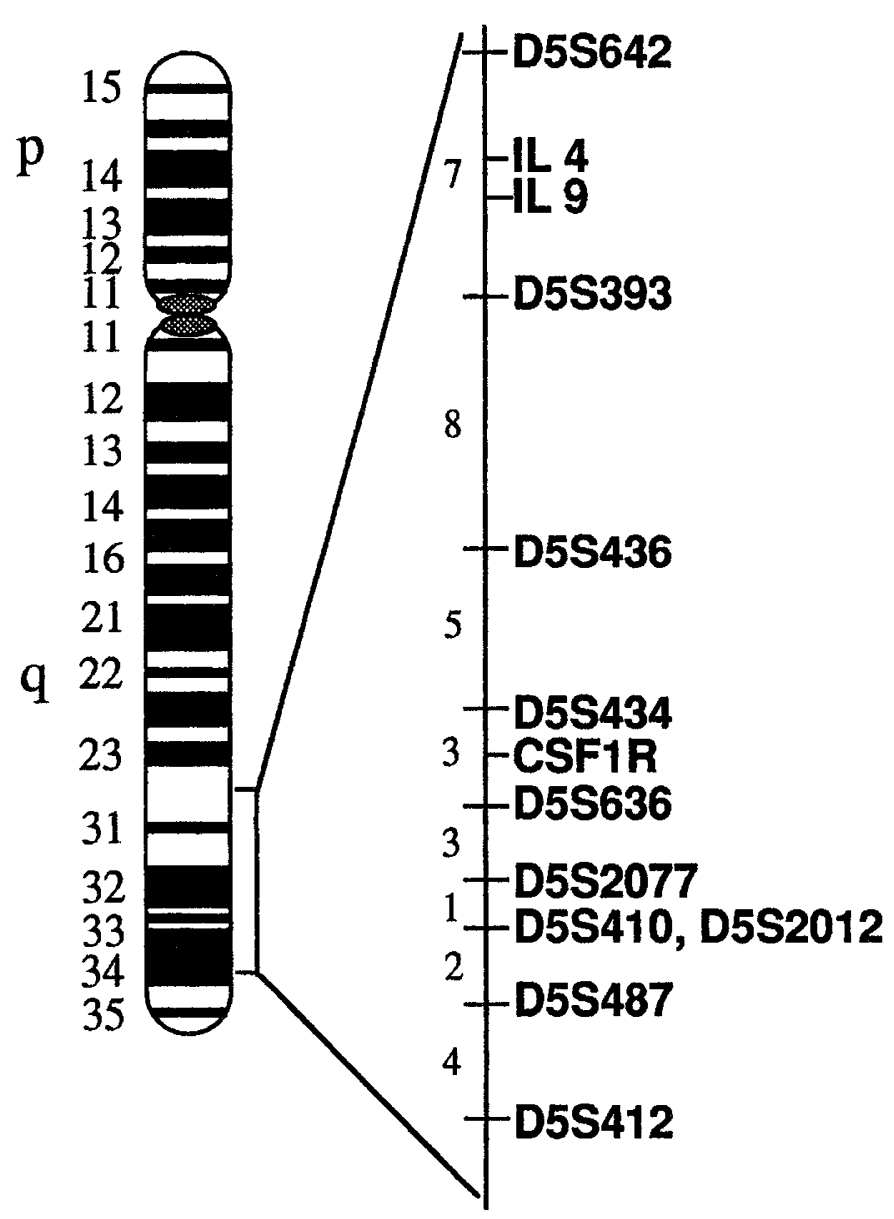

$\operatorname{Zmax}(\theta) \quad$ Candidate Genes

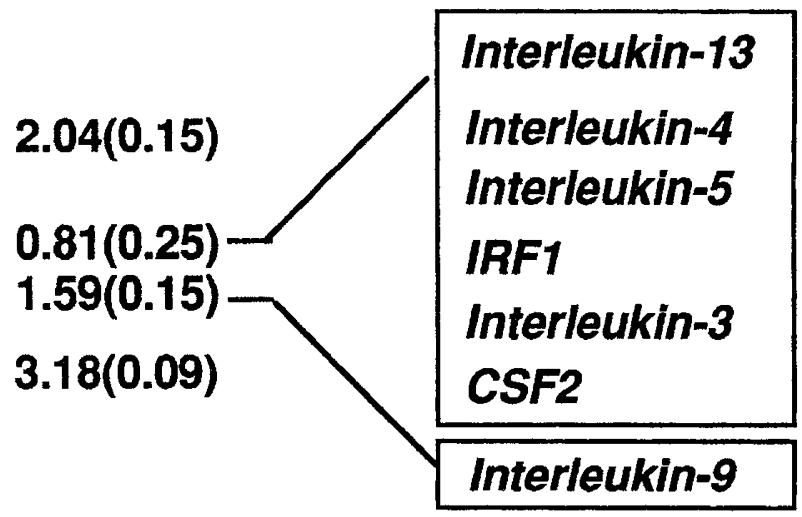

2.14(0.16)

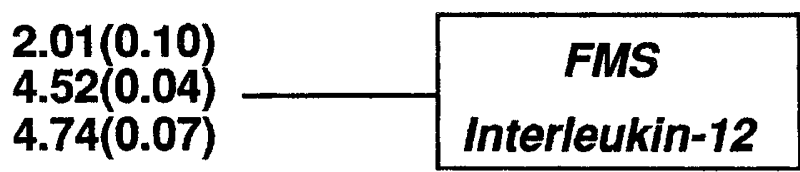

2.00(0.12)

$3.06(0.15) 3.14(0.13)$

2.28(0.14)

$1.88(0.17)$

Figure $1 \mathrm{M}$ ap of chromosome 5 showing the relative order of and distance between the polymorphic genetic markers used and the approximate location of the candidate genes. The order and distance (cM) between these genetic markers in $5 q 31-q 33$ region are based on genetic map ${ }^{18,19}$ except for the intragenic markers interleukin-4 (IL 4) and IL 9. ${ }^{13}$ CSF IR was placed on the basis of our multipoint analysis. Maximum two-point lod scores and recombination fractions $(\theta)$ are indicated for each marker. The map includes the following genes: IL 13, IL 4, IL5, interferon regulatory factor-1 (IRF1), IL 13, granulocyte-macrophage colony stimulating factor (CSF2), IL 9, IL 12 and FM gene which encodes a colony stimulating factor-1 receptor (CSF 1R).

means of the phenotype adjusted for covariates, $\mu \mathrm{AA}, \mu \mathrm{A}$ a and $\mu a a$, corresponding to the three genotypes, $A A, A$ and aa; given the genotype, the distribution of the phenotype is assumed to be normal. The dependence on relative phenotypes is expressed in terms of phenotypic correlations, and the effects of covariates are parametrised using regression coefficients. The present analysis was performed using the program REGRESS, ${ }^{16}$ which incorporates the regressive approach into the LINKAGE package ${ }^{17}$ and allows simultaneously the effect of covariates (water contact, age, sex) with the major gene to be estimated.

\section{Linkage Analysis}

The linkage study strategy was a genome-wide search using microsatellites markers. The genome-wide search was per- formed on 142 subjects belonging to two large pedigrees (pedigrees 1 and 8 comprising 50 and 20 individuals, respectively), five smaller pedigrees (pedigrees $2,3,4,5$, and 7 , including $12,9,14,6$ and 7 individuals, respectively), and four nuclear families (families 30, 40, 120, and 131 with 7, 5, 6, 6 subjects, respectively). These families are shown in Figure 2. The primary map consisted of 246 markers from the Généthon panel ${ }^{18,19}$ with an average interval spanned by adjacent markers estimated to be $15 \mathrm{cM}$; no interval was greater than $35 \mathrm{cM}$, and 5 intervals were between 25 and $35 \mathrm{cM}$.

A s segregation analysis provided evidence for a major gene model in the control of S. mansoni infection levels, we used a parametric lod-score approach to test for linkage. ${ }^{20}$ For this analysis, E 2 values were adjusted on the basis of covariates 

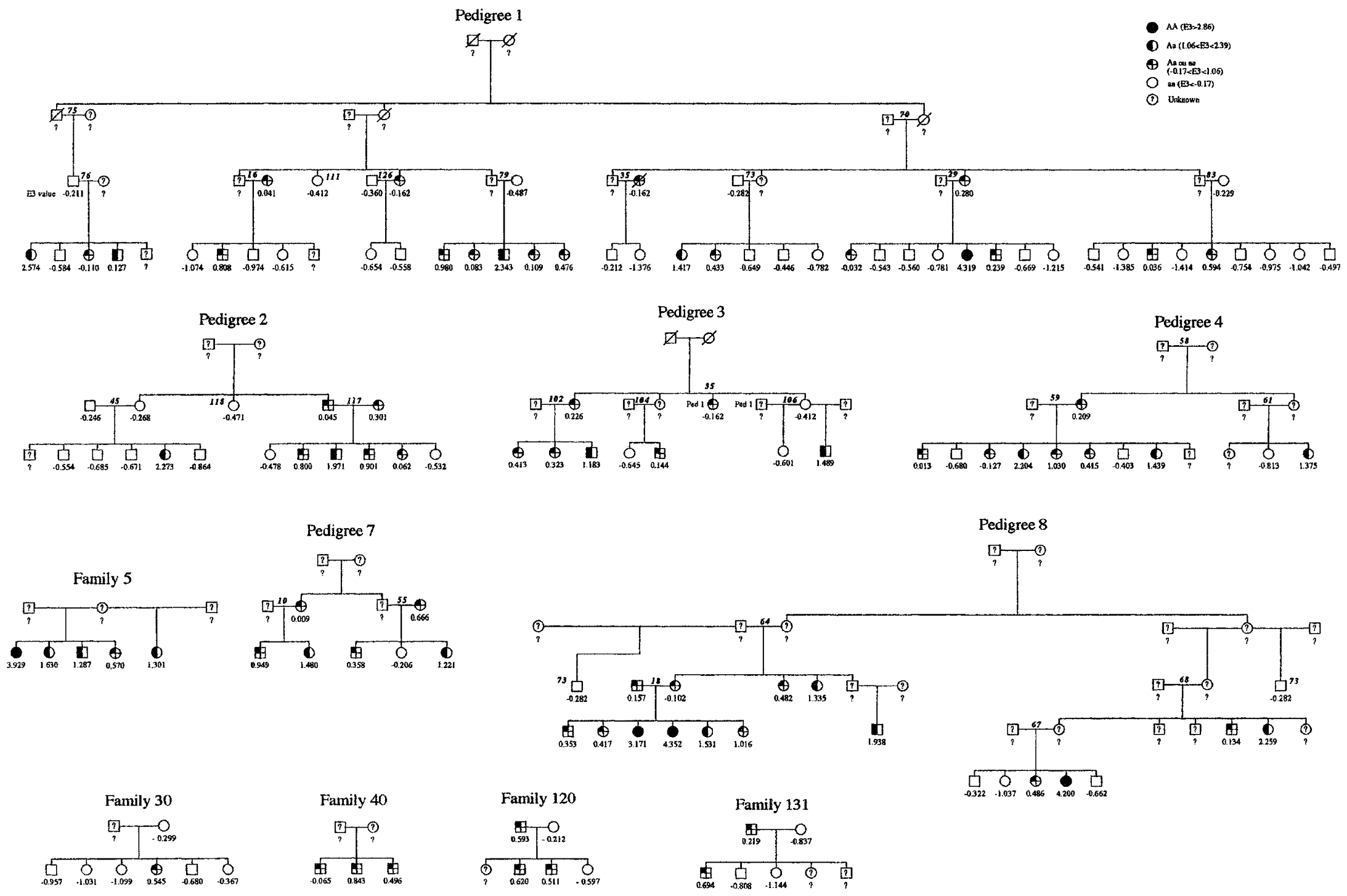

Figure 2 Familial structure for two large pedigrees (numbers 1, 8), five smaller pedigrees (numbers 2, 3, 4, 5, 7) and four nuclear families (numbers $30,40,120$, 131) used for linkage analysis. In the pedigree the number of the nuclear family is indicated in bold italic. For each subject the adjusted standardised infection intensity (E 3 value) is specified and a genotype is assigned when its probability is greater than 0.9 based on E 3 values. Subjects with ? for E 3 value and genotype are classified as unknown, they correspond to subjects without E 1 value expressed in eggs/gram or subjects with the lowest water contact level. 
that had a significant effect (sex, age and water contact) using the regression coefficients obtained under the major gene model of best fit; the standardised residuals were denoted as E 3. Two point lod-score analyses were computed by means of the LINKAGE package ${ }^{17}$ using the maximum likelihood major gene parameters obtained from the segregation analysis. The frequency of allele $A$ predisposing to high $E 3$ values was 0.16 , and the three $\mathrm{E} 3$ means were $3.96,0.78$ and -0.43 , for $A A, A$ and aa individuals, respectively, with a residual variance equal to 0.33 . The marker allele frequencies were assumed to be equal as some alleles found in this Brazilian population were not typed in the $\mathrm{CEPH}$ reference families. For the 5q31-q33 markers, the analysis was also performed considering allele frequencies estimated from our data. Multipoint analysis in the 5q31-q33 region was performed using the VITE SSE program. $^{21}$

\section{Results}

\section{Segregation Analysis}

$R$ esults confirmed the presence of a codominant major gene controlling infection intensities with parameters close to those of the previous analysis. ${ }^{6}$ This gene, referred to as SM 1, accounted for $66 \%$ (50\% in the first study) of the infection intensity variance residual from covariate effects. The frequency of the allele $A$ predisposing to high infection was 0.16 (around 0.2 in the first study). Then, under this genetic model, about $3 \%$ of the study population were homozygous for the deleterious allele and predisposed to high infections, 70\% were resistant, and $27 \%$ of the study population were heterozygous and had an intermediate, although fairly strong, level of resistance.

\section{Linkage Analysis}

The maximum lod-score values obtained with the various microsatellites are presented in Figure 3 for each chromosome. Maximum lod scores greater than 0.1 were observed with 54 markers (Figure 4), and were distributed on almost all chromosomes (Figure 3). Six markers located in four regions on chromosomes $1,5,7$, 21 yielded maximum lod scores greater than 0.83 $(P<0.025)$. It was striking that only two adjacent microsatellites in region 5q31-q33, D5S393 and D 5S410, gave a maximum lod score $\left(Z_{\max }\right)$ above 3.0, while all other markers produced $Z_{\max }$ below 1.1 (Figure 4). The 5q31-q33 chromosomal interval was further analysed by genotyping 11 additional markers (Figure 1), and significant evidence of linkage (considered as a lod-score value above 3.3 according to $\mathrm{L}$ ander and $\mathrm{K}$ ruglyak $^{22}$ in this context of genome-wide search) was obtained with two closely linked markers: D5S636 $\left(Z_{\max }=+4.74, \quad \theta=0.07\right)$ and CSF 1R $\left(Z_{\text {max }}=+4.52, \theta=0.04\right)$ using estimated marker allele frequencies. ${ }^{7}$ For most of the markers the linkage information came from the two large pedigrees numbered 1 and 8, and haplotype co-segregation with high infection levels within these two pedigrees was given in our first report. ${ }^{7} \mathrm{H}$ ere we present the detailed twopoint lod-score results for D5S636 and CSF 1R within each family (Table 1). Multipoint linkage analysis confirmed the mapping to 5q31-q33 with a multipoint lodscore value above +5.5 and a most likely location of SM 1 in close proximity to CSF $1 R$. $^{7}$

Whereas significant linkage of SM 1 was obtained with only one region, four additional markers in three other regions provided lod-score values above 0.83 : $1 p 22.2$ with $D 1 S 216\left(Z_{\max }=+0.91, \quad \theta=0.20\right)$, 21q22-qter with D21S1259 $\left(Z_{\max }=+1.09, \theta=0.19\right)$, and the two adjacent markers $D 7 S 483\left(Z_{\text {max }}=+0.91\right.$, $\theta=0.20)$ and $D 7 S 550\left(Z_{\text {max }}=+1.02, \theta=0.22\right)$ in the $7 q 36$ region. These results could be due to the large number of tests performed in a genome-wide search, but it is interesting to note that some genes involved in the immune response against schistosomes are located in these regions. The beta $T$ cell receptor $(T C R \beta)$ is assigned close to the $7 q 36$ region, ${ }^{23}$ and chromosome 21 includes the human interferon $\alpha$ receptor gene (IFN $\alpha \mathrm{R})$ in $21 \mathrm{q} 22.1^{24}$ and the human interferon $\beta$ receptor gene (IF N $\beta$ R) in 21q22.2. ${ }^{23}$ Finally, the interleukin-12 receptor $\beta 2$ chain was recently localised to chromosome 1p31.3-p31.2 by in situ hybridisation. ${ }^{25}$

\section{Discussion}

The results presented here map the codominant major gene controlling human susceptibility/resistance to $\mathrm{S}$. mansoni, SM 1, and are the first example of a successful genome-wide scan in the study of susceptibility/resistance to infectious diseases. A new segregation analysis allowed us to refine the model for SM 1 which was used in the parametric linkage analysis. W ith this parametric approach, a single region on chromosome $5 q 31-q 33$ was found to be significantly linked to disease. R ecently, M üller-M yhsok et $\mathrm{al}^{26}$ confirmed this localisation by means of a nonparametric linkage method in a Senegalese population infected with S. mansoni and exposed for no longer than 7 years. ${ }^{26}$ These two studies emphasise the importance of the locus SM 1 which influences the intensity of infection by $\mathrm{S}$. mansoni.

The $5 q 31-q 33$ region where SM 1 is located contains several candidate loci involved in the regulation of the immune response to pathogens, in particular genes coding for interleukin-4 (IL 4), ${ }^{13,27}$ IL 5, ${ }^{13,27}$ IL $12,{ }^{28}$ the 

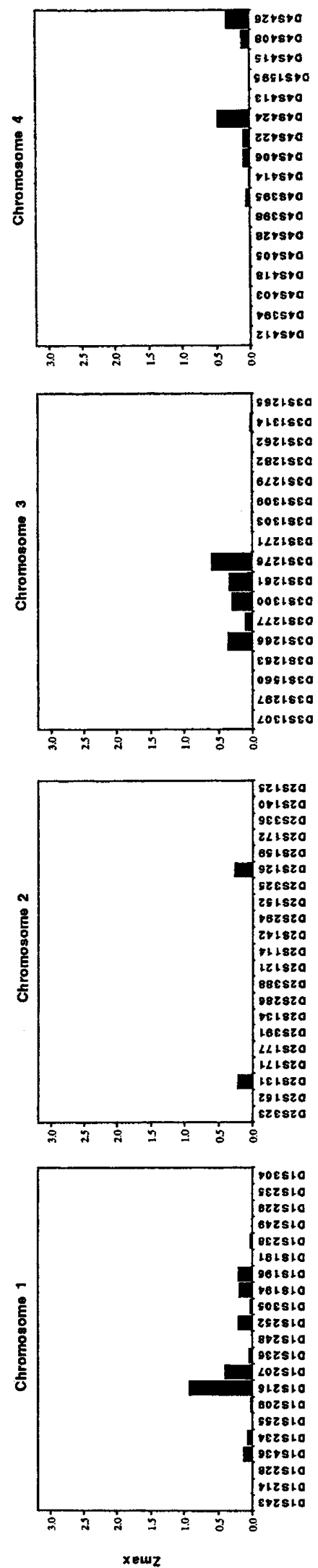
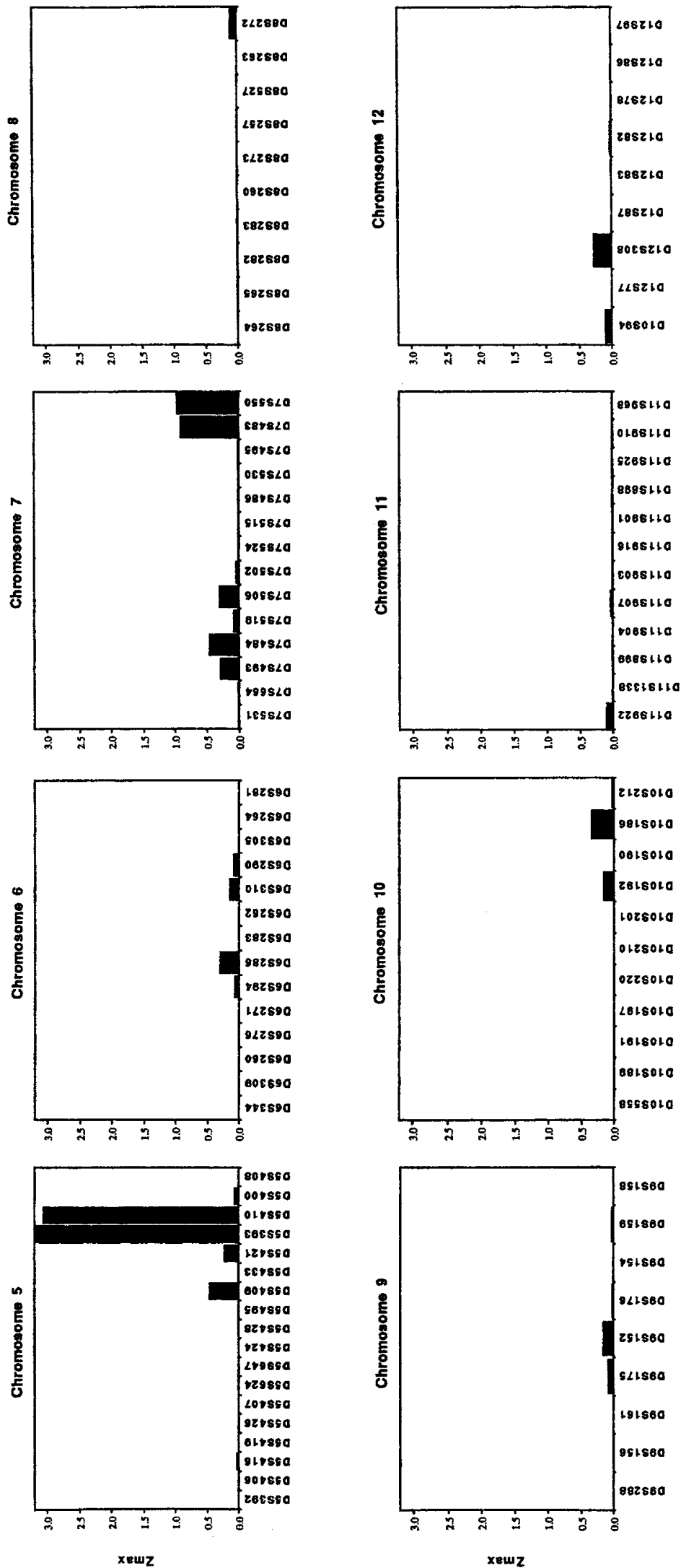

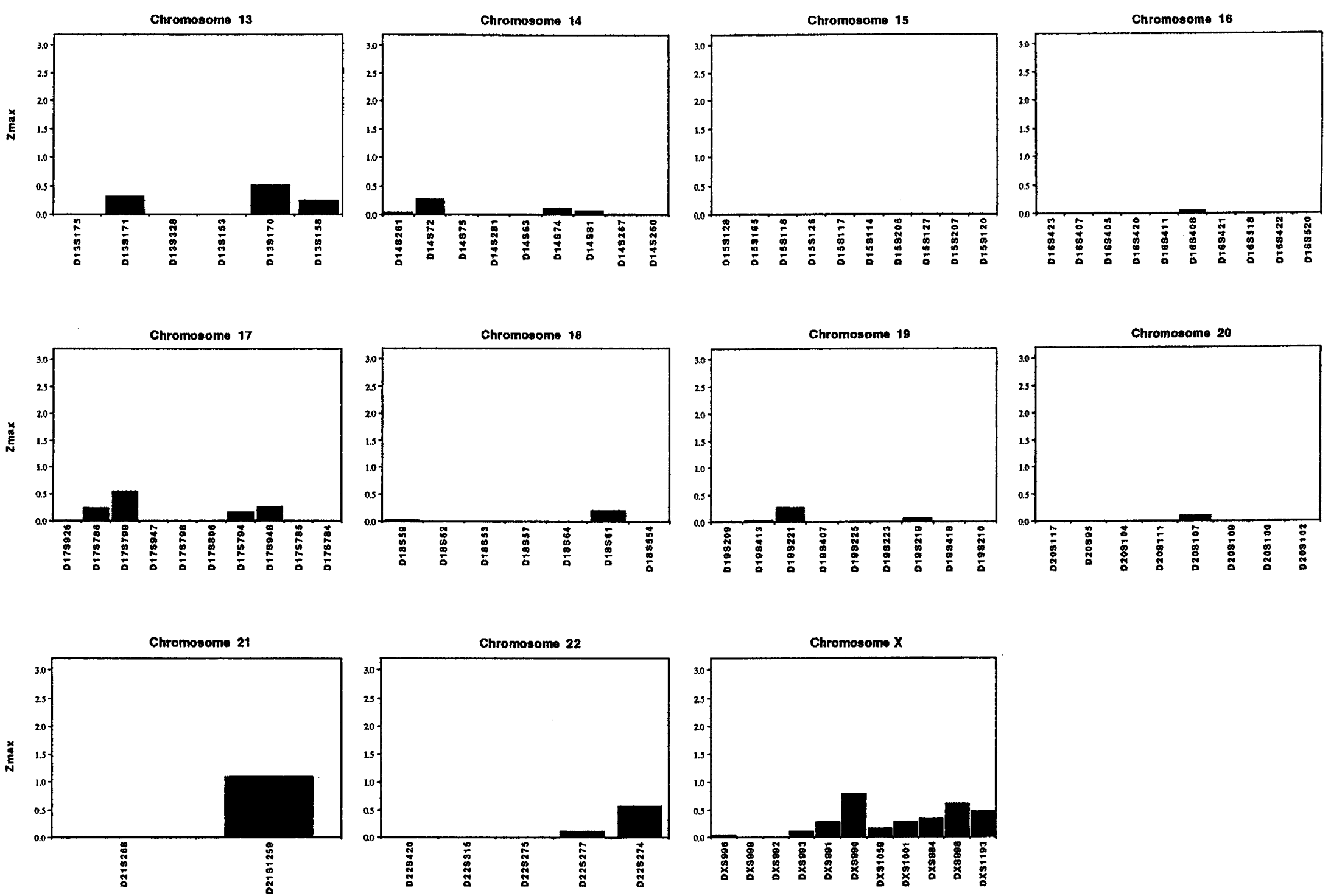

Figure 3 Maximum lod scores $\left(Z_{\max }\right)$ by chromosome for the genomic screen of infection levels by Schistosoma mansoni. L od-score values for 246 markers analysed are on the vertical axis; some of the markers used for the primary map are listed below the histogram. 


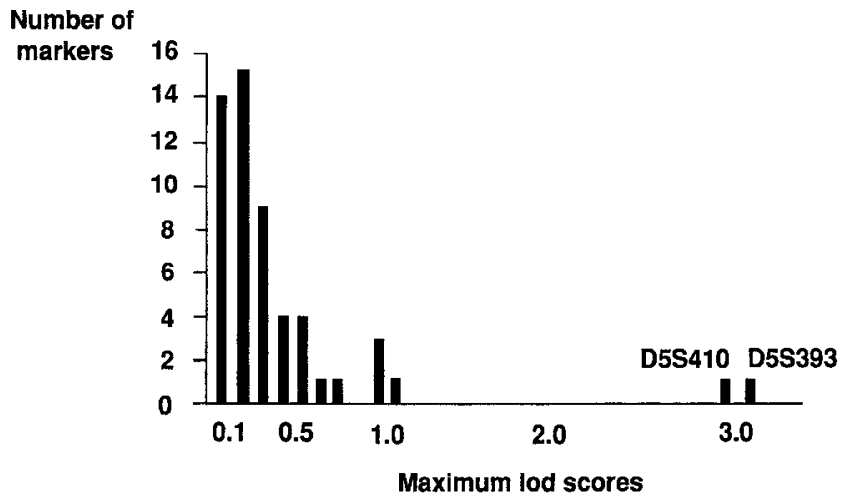

Figure $4 \mathrm{H}$ istogram of 54 markers with $\mathrm{Z}_{\max }>0.1$.

Table 1 Two-point lod scores for chromosome 5q31-33 markers in families affected by schistosomiasis showing evidence against linkage to SM 1 . These results were obtained using estimated marker allele frequencies

\begin{tabular}{|c|c|c|c|c|}
\hline \multirow[b]{3}{*}{ Family } & \multicolumn{4}{|c|}{$\begin{array}{l}\text { Two-point lod scores at recombination } \\
\text { fractions of } 0.00 \text { and } 0.05\end{array}$} \\
\hline & \multicolumn{2}{|c|}{ D 5S636 } & \multicolumn{2}{|c|}{ CSF 1R } \\
\hline & 0.00 & 0.05 & 0.00 & 0.05 \\
\hline 1 & 2.63 & 3.10 & 1.57 & 2.36 \\
\hline 2 & -0.44 & 0.04 & 0.98 & 0.78 \\
\hline 3 & 0.20 & 0.17 & 0.17 & 0.14 \\
\hline 4 & 0.06 & 0.08 & -0.04 & -0.04 \\
\hline 5 & -0.49 & -0.33 & -0.49 & -0.33 \\
\hline 7 & -0.20 & -0.14 & 0.16 & 0.14 \\
\hline 8 & 2.09 & 1.90 & 1.83 & 1.58 \\
\hline 30 & -0.02 & -0.01 & -0.02 & -0.01 \\
\hline 40 & 0.07 & 0.06 & 0.07 & 0.06 \\
\hline 120 & -0.08 & -0.06 & -0.08 & -0.06 \\
\hline 131 & -0.13 & -0.10 & -0.14 & -0.11 \\
\hline Total & 3.69 & 4.71 & 4.03 & 4.52 \\
\hline
\end{tabular}

interferon regulatory factor 1 (IR F 1$)^{27}$ which encodes a transcriptional activator of interferon-alpha (IFN $\alpha$ ), interferon-beta (IFN $\beta$ ) and other IFN-inducibles genes, and finally CSF $1 R$. ${ }^{27}$ Furthermore, this region has been linked with loci related to IgE and/or eosinophilia production, ie a locus regulating I $g E$ levels, ${ }^{13,29}$ a locus controlling bronchial hyper-responsiveness in asthma, ${ }^{30}$ and a locus involved in familial hypereosinophilia. ${ }^{31}$ This localisation of SM 1 is consistent with the immunological analyses carried out on both blood lymphocytes and T-cell clones derived from susceptible (A A) subjects and resistant (aa) subjects. The larval and wormspecific T-lymphocytes from aa subjects produced larger amounts of IL 4 and IL 5 than T-cells from A A subjects. In contrast T-lymphocytes from A A subjects produced larger amounts of interferon-gamma (IFN $\gamma$ ) than T-cells from aa subjects. These results indicate that the parasite specific T-lymphocytes of resistant subjects are Th0/2-like, ${ }^{32}$ while susceptible subjects exhibit a Th0/1-like response (Rodrigues $V$, D essein A unpublished data 1998), and are consistent with the previous results indicating that resistance to infection by $\mathrm{S}$. mansoni is associated with a high parasite specific IgE antibody response ${ }^{33-35}$ that is dependent on IL 4 and downregulated by IFN $\gamma$. The development of Th1 or Th2 cells is mainly regulated by certain cytokines, especially IL 12 and IL 4, when present during primary T-cell activation. $A$ t this time, we cannot exclude any of these candidate genes localised in the 5q31-q33 region.

Three other chromosomal regions, $1 p 22.2,7 q 36$ and 21q22-qter provided lod-score values above 0.83 . A Ithough these values are not significant in the context of a genome-wide search, it is interesting to note that some candidate genes are located within these regions. The IL 12 receptor $\beta 2$ chain is located close to the 1p22.2 region, ${ }^{25}$ and plays an important role in the immune response, since the interaction between IL 12 and its receptor induces the secretion of IF $\gamma \gamma$ and stimulates differentiation of $\mathrm{T}$ helper 1 (Th1) cells. The IL 12 receptor $\beta 2$ subunit is expressed on human Th1 but not Th2 clones, and is induced during differentiation of human naive cells along Th1 but not Th2 pathways. $^{36}$ A nother potential region of interest is 21q22-qter, where the interferon-alpha receptor (IFN $\alpha R$ ) and interferon-beta receptor (IFN $\beta R$ ) are located. It was recently demonstrated that the production of the cytokines IL 12 and IFN $\gamma$ is inhibited by interferon $\alpha$ and $\beta$ (IFN $\alpha / \beta)$. ${ }^{37}$ Finally the $7 q 36$ region contains the beta T cell receptor (TCR $\beta$ ), and T cells were shown to play a central role in the development of acquired immunity against schistosomes.

The main interest of the present genome-wide screen strategy compared with a candidate gene approach is to ensure that all major loci involved in the control of infection by S. mansoni are identified, and to provide the opportunity to discover new major genes, and consequently physiopathological pathways, that were not previously suspected of contributing to this control. However, since we used a parametric linkage method to localise SM 1, it is possible that the major gene model employed in the present analysis was not appropriate for investigating the role of loci in addition to the one identified in 5q31-q33. Therefore, the identification of additional putative loci that could be involved in the control of intensity of infection by S. mansoni will require the use of nonparametric linkage methods 
which do not need to specify the major gene model. The weighted pairwise correlation method, ${ }^{38,39}$ which is a nonparametric linkage method for general pedigrees, appears to be the method of choice for the Brazilian population studied here, and we could use a recent twolocus extension of this method ${ }^{40}$ which will allow us to test for the presence of a second locus taking into account the 5q31-q33 locus. The role of these regions will also be assessed by replication studies performed in other populations.

In conclusion, these data present the first successful genome-wide scan to map a major gene of susceptibility/resistance to infectious diseases. The full results show that only one region on chromosome $5 q 31-q 33$ was significantly linked to schistosomiasis. Further nonparametric two-locus linkage studies will assess the role of additional putative genes.

\section{Acknowledgements}

We thank S Fauré and the genotyping laboratory from $G$ énéthon for helpful assistance, $F$ D emenais for providing the REGRESS software, and M M orton for critical reading of the manuscript. This work was supported in part by grants 492N S3 from I N SE R M , TS3-CT 94-0296 from E C, 51/93 from GREG, and by INSERM/CNPQ exchange grants.

\section{References}

1 UNDP/World Bank/WHO: Schistosomiasis. In: Tropical D iseases: Progress in R esearch. :W H O : G eneva, 1990, pp 41-48.

2 Butterworth A E, Capron M, Cordingley IS et al: Immunity after treatment of human schistosomiasis. II. Identification of resistant individuals and analysis of their immune responses. Trans R Soc Trop M ed H yg 1985; 79: 393-408.

$3 \mathrm{H}$ agan $\mathrm{P}, \mathrm{B}$ lumenthal $\mathrm{UJ}$, Chaudri $\mathrm{M}$ et al: R esistance to reinfection with Schistosoma haematobium in $\mathrm{G}$ ambian children: analysis of their immune response. Trans $R$ Soc Trop M ed H yg 1987; 81: 938-946.

4 Wilkins HA, Blumenthal UJ, Hagan P, Tulloch S, Hayes $\mathrm{RJ}$ : R esistance to reinfection after treatment of urinary schistosomiasis. Trans R Soc Trop Med Hyg 1987; 81: 29-35.

5 D essein A J, B egley M, D emeure $C$ et al: $H$ uman resistance to Schistosoma mansoni is associated with IgG reactivity to a 37-kD a larval surface antigen. J Immunol 1988; 140: 2727-2736.

6 A bel L, Demenais F, Prata A, Souza AE, Dessein A: $E$ vidence for the segregation of a major gene in human susceptibility/resistance to infection by Schistosoma mansoni. A m J Hum G enet 1991; 48: 959-970.
$7 \mathrm{M}$ arquet $S, A$ bel $L, H$ illaire $D$ et al: $G$ enetic localization of a locus controlling the intensity of infection by Schistosoma mansoni on chromosome 5q31-q33. N at G enet 1996; 14: $181-184$

8 D essein A J, A bel L, Coussinier P et al: Environmental, genetic and immunological factors in human resistance to Schistosoma mansoni. I mmunol I nvest 1992; 21: 423-453.

9 D emeure CE, R ihet P, A bel L, O uattara M, B ourgois A, Dessein AJ: Resistance to Schistosoma mansoni in humans: influence of the IgE/IgG 4 balance and IgG 2 in immunity to reinfection after chemotherapy. J Infect $D$ is 1993; 168: 1000-1008.

10 Sambrook J, Fritsch EF, M aniatis T: Molecular Cloning. Cold Spring $\mathrm{H}$ arbor Laboratory Press: New York, 1989.

11 Vignal A, Gyapay G, H azan J et al: A non-radioactive multiplex procedure for genotyping of microsatellites markers. In: A dolph KW (ed.). M ethods in Molecular Genetics 1: G ene and Chromosome A nalysis. A cademic Press: San Diego, 1993, pp 211-221.

12 Mout R, Willemze R, L andegent JE: R epeat polymorphisms in the interleukin-4 gene (IL 4). N ucleic A cids Res 1991; 19: 3763.

13 Marsh DG, Neely JD, B reazeale DR, et al: Linkage analysis of IL 4 and other chromosome 5 q31.1 markers and totral serum immunoglobulin $\mathrm{E}$ concentrations. Science 1994; 264: 1152-1156.

14 Polymeropoulos $\mathrm{MH}, \mathrm{X}$ iao $\mathrm{H}, \mathrm{R}$ ath DS, Merril CR: $D$ inucleotide repeat polymorphism at the human c-fms proto-oncogene for the CSF-1 receptor (CSF 1R). N ucleic A cids Res 1991; 19: 1160.

15 Bonney GE: On the statistical determination of major gene mechanisms in continuous human traits: regressive models. A m J M ed G enet 1984; 18: 731-749.

16 Demenais FM, Lathrop M: REGRESS: A computer program including the regression approach into the LINK A G E package. G enet E pidemiol 1994; 11: 291.

17 Lathrop G M, Lalouel J M, Julier C, Ott J: Strategies for multilocus linkage analysis in humans. Proc $\mathrm{N}$ atl $\mathrm{A}$ cad $\mathrm{Sci}$ USA 1984; 81: 3443-3446.

18 G yapay G, Morisette J, Vignal A, et al: The 1993-94 $\mathrm{G}$ énéthon human genetic linkage map. $\mathrm{N}$ at $\mathrm{G}$ enet 1994; 7: 246-339.

19 Dib C, Fauré S, Fizames $C$ et al: A comprehensive genetic map of the human genome based on 5,264 microsatellites. N ature 1996; 380: 152-154.

20 M orton NE : Sequential tests for the detection of linkage. A m J H um G enet 1955; 7: 277-318.

210 'C onnell JR, Weeks DE: The VITESSE algorithm for rapid exact multilocus linkage analysis via genotype setrecoding and fuzzy inheritance. Nat Genet 1995; 11: 402-408.

22 Lander E, K ruglyak L: G enetic dissection of complex traits: guidelines for interpreting and reporting linkage results. N at G enet 1995; 11: 241-247.

23 Frezal J (ed.): G enome Interactive D atabases. John L ibbey E urotext: 1996; vol 3(2). France.

24 L utfalla G, G ardiner K, Proudhon D, Vielh E, U ze G: The structure of the human interferon $\alpha / \beta$ receptor gene. J Biol Chem 1992; 267: 2802-2809.

25 M orton SM, B ocaccio I, D epetris D, M attei M, D essein A : A ssignment of IL $12 \mathrm{R} \beta 2$ to human chromosome 1p31.3-p31.2 between D 1S230 and D 1S198. Cytogenet C ell Genet 1997; 79: 282-283. 
26 M üller-M yhsok B, Stelma FF, G uissé-Sow $F$ et al: Further evidence suggesting the presence of a locus on human chromosome $5 q 31-q 33$ influencing the intensity of infection with Schistosoma mansoni. A m J H um G enet 1997; 61: 452-454.

27 Saltman D L, D olganov G M, Warrington JA, Wasmuth JJ, L ovett $M$ : A physical map of 15 loci on human chromosome 5q23-q33 by two-color fluorescence in situ hybridization. Genomics 1990; 16: 726-732.

28 Boultwood J, Fidle C, L ewis S et al: M olecular mapping of uncharacteristically small $5 q$ deletions in two patients with $5 q$-syndrome: $D$ elineation of the critical region on $5 q$ and identification of a 5q-breakpoint. Genomics 1994; 19: 425-432.

29 Meyers DA, Postma DS, Panhuysen CIM et al: E vidence for a locus regulating total serum IgE levels mapping to chromosome 5 . G enomics 1994; 23: 464-470.

30 Postma DS, Bleecker ER, A melung PJ et al: Genetic susceptibility to asthma - Bronchial hyperresponsiveness coinherited with a major gene for atopy. N Engl J Med 1995; 333: 894-900.

31 Lin AY, Rioux J D, Nutman T et al: A gene for familial hypereosinophilia maps to chromosome 5q31-q33. A m J H um G enet 1997; Suppl 61: A 283.

32 Couissinier-Paris P, D essein AJ: Schistostoma-specific helper $\mathrm{T}$ cell clones from subjects resistant to infection by Schistosoma mansoni are Th0/2. E ur J I mmunol 1995; 25: 2295-2302.
33 Rihet $P, D$ emeure $C$, B ourgois A, D essein A J : Evidence for an association between human resistance to Schistosoma mansoni and high anti-larval IgE levels. Eur J Immunol 1991; 21: 2679-2686.

34 H agan $P, B$ lumenthal U J, D unne D, Simpson A J G, Wilkins $\mathrm{HA}$ : H uman IgE , IgG 4, and resistance to reinfection with Schistosoma haematobium. Nature 1991; 349: 243-245.

35 D unne DW, B utterworth A E , Fulford A J C et al: I mmunity after treatment of human schistosomiasis: association between IgE antibodies to adult worm antigens and resistance to reinfection. Eur J Immunol 1992; 22: 1483-1494.

36 Rogge $L$, Barberis-M aino $L$, Biffi $M$ et al: Selective expression of an interleukin-12 receptor component by human T helper 1 cells. J Exp M ed 1997; 185: 825-831.

37 Cousens L P, O range J S, Su H C, B iron CA : Interferon- $\alpha / \beta$ inhibition of interleukin-12 and interferon- $\gamma$ production in vitro and endogenously during viral infection. Proc $\mathrm{N}$ atl A cad Sci USA 1997; 94: 634-639.

38 Commenges D: R obust genetic linkage analysis based on a score test of homogeneity: the Weighted Pairwise Correlation statistic. G enet E pidemiol 1994; 11: 189-200.

39 Commenges $D, A$ bel $L$ : I mproving the robustness of the WPC test for linkage analysis. G enet E pidemiol 1996; 13: 559-573.

40 Zinn-Justin A, A bel L: Two-locus developments of the Weighted Pairwise Correlation method for linkage analysis. G enet E pidemiol (in press). 